\title{
ALLERGIC CONTACT DERMATITIS DUE TO SEMECARPUS ANACARDIUM
}

\author{
K. Venkatachalam ${ }^{1}$, Shaik Asha², Chenna Subhashini ${ }^{3}$, P. Anila Sunandini' ${ }^{4}$ Padmasri Soma Y5, Ch. Naveen Kumar ${ }^{6}$, Swetha Naidu K7, \\ Amrutha Bindu $S^{8}$
}

${ }^{1}$ Assistant Professor, Department of DVL, KGH, Visakhapatnam.

2Postgraduate Student, Department of DVL, KGH, Visakhapatnam.

${ }^{3}$ Assistant Professor, Department of DVL, KGH, Visakhapatnam.

${ }^{4}$ Professor, Department of DVL, KGH, Visakhapatnam.

${ }^{5}$ Senior Resident, Department of DVL, KGH, Visakhapatnam.

${ }^{6}$ Postgraduate Student, Department of DVL, KGH, Visakhapatnam.

7 Postgraduate Student, Department of DVL, KGH, Visakhapatnam.

${ }^{8}$ Postgraduate Student, Department of DVL, KGH, Visakhapatnam.

\begin{abstract}
BACKGROUND

Allergic contact dermatitis is a cell mediated type IV, delayed type hypersensitivity reaction caused by having skin contact with an environmental allergen whose prior sensitisation to a chemical is required for allergy to develop. This study was designed to diagnose the allergic contact dermatitis in a patient who had direct contact with Semecarpus anacardium seeds based on history and clinical examination findings.
\end{abstract}

\section{MATERIALS AND METHODS}

A total of 75 patients of Allergic Contact Dermatitis who had contact with Semecarpus anacardium were selected based on history of exposure and the objective of the study is to diagnose the case of ACD on looking at the clinical presentation of the patient just based on history given by the patient.

Study Design- The present study was a descriptive study.

Study Setting- DVL Department, Andhra Medical College, King George Hospital, Visakhapatnam, Andhra Pradesh, India.

Objectives of the Study- The objectives of the study is to show various patterns of clinical presentation and age distribution among those patients based on history of exposure to Semecarpus anacardium by using cross descriptive type of study done at King George Hospital, Visakhapatnam.

\section{RESULTS}

A total of 75 subjects who had direct contact with Semecarpus anacardium Linn seeds were found to be sensitive and develop allergic contact dermatitis and we diagnosed the cases based on history, onset and duration of clinical findings after exposure.

\section{CONCLUSION}

Patients who had direct contact or exposed to the smoke of Semecarpus anacardium Linn Seeds are prone for development of both allergic and irritant contact dermatitis.

\section{KEYWORDS}

Semecarpus Anacardium Linn, Urushiol, Allergic Contact Dermatitis.

HOW TO CITE THIS ARTICLE: Venkatachalam K, Asha S, Subhashini C, et al. Allergic contact dermatitis due to semecarpus anacardium. J. Evolution Med. Dent. Sci. 2017;6(92):6655-6657, DOI: 10.14260/jemds/2017/1441

\section{BACKGROUND}

Contact dermatitis is a condition in which the skin becomes red, sore or inflamed after direct contact with a substance. There are two kinds of contact dermatitis: Irritant or Allergic. Most often this occurs when something that touches the skin causes irritation (Irritant contact dermatitis) or an allergic reaction (Allergic contact dermatitis).

'Financial or Other Competing Interest': None.

Submission 10-11-2017, Peer Review 21-11-2017,

Acceptance 24-11-2017, Published 04-12-2017.

Corresponding Author:

Dr. Chenna Subhashini,

C/o. C. Sudhakar,

Flat No. 104 and 105,

Gajanana Apartments,

Santhinagar, NAD, Kotha Road,

Visakhapatnam-530009,

Andhra Pradesh.

E-mail: chennasubhasubhashini@gmail.com

DOI: $10.14260 /$ jemds $/ 2017 / 1441$
Allergic contact dermatitis is an eczematous reaction that occurs as an immunological response following exposure to a substance to which the immune system has previously been sensitised. However, the true incidence of ACD in a society is very difficult to estimate, since its diagnosis depends on several factors such as the demographic profile common sensitisers also vary with place, patient profile and over the passage of time. Since optimal treatment of patients with ACD is predicted on accurate advice about prevention, regular patch testing followed by estimation of relevance is imperative in all suspected cases.

Semecarpus Anacardium Linn, (Family: Anacardiaceae), is the nut commonly known as 'marking nut' and in the vernacular as 'Ballataka' or 'Bhilawa,' has been used in various traditional system of medicines for various ailments since ancient times. Its nuts contain a variety of biologically active compounds such as biflavonoids, phenolic compounds, bhilawanols, minerals, vitamins and amino acids, which show various medicinal properties. The fruit and nut extract shows various activities like anti-atherogenic, anti-inflammatory, 
antioxidant, antimicrobial, anti-reproductive, CNS stimulant, hypoglycaemic, anticarcinogenic and hair growth promoter. ${ }^{1,2}$ Tarry oil present in the pericarp of the fruit contain Anacardic Acid that contains urushiols, which cause blisters on contact.

So, there is every chance of accidental poisoning causing contact dermatitis in children, and also in adults most commonly during the time of Dussera. The diagnosis is made with the help of history of patient and patch test. Patch testing helps identify which substances may be causing a reaction in a patient. Present study therefore attempts to determine the feasibility of diagnosis of allergic contact dermatitis in patients having contact dermatitis using Semecarpus anacardium as evils eye. ${ }^{3}$

The evil eye is a malevolent look that many cultures believe are able to cause injury or misfortune for the person at whom it is directed for reasons of envy or dislike. The burinazar (evil eye) is a big deal in India.

It is commonly believed that should someone curse you with it, the negative energy will bring about all kinds of illnesses and misfortunes. The threat of this prompts people into taking enthusiastic protective actions ranging from drawing big black dots on babies' foreheads to chanting mantras and engaging the services of pundits (hindu priests) and astrologers to ward it off. Practice of getting rid of evils eye using Semecarpus anacardium Linn seeds is very common in our Vizag region from AP, India, during the period of Dussera. Procedure is commonly done by females in which they use Semecarpus anacardium Linn seeds, they waive seeds from top to bottom of children and then burn these seeds and the smoke produced cause allergic contact dermatitis in susceptible individuals.

\section{MATERIALS AND METHODS}

This study comprised of total of 500 subjects, out of which 75 presented with history of exposure to Semecarpus anacardium, using it as a remedy for evils eye in Visakhapatnam region of India attending the outpatient department of DVL. At Andhra Medical College and KGH, Vizag, India, during the months of Dussera in 2016 and 2017 were selected.

\section{Study Design}

The present study was a descriptive study.

\section{Study Setting}

DVL Department, Andhra Medical College, King George Hospital, Visakhapatnam, Andhra Pradesh, India.

\section{Objectives of the Study}

The objectives of the study is to show various patterns of clinical presentation and age distribution among those patients based on history of exposure to Semecarpus anacardium by using cross descriptive type of study done at King George Hospital, Visakhapatnam.

\section{Patient Evaluation}

A special proforma was prepared to include all the details including age, sex and occupation. Detailed history was also taken with the onset, duration and evaluation of symptoms, constitutional and systemic disturbances, pre-existing skin disease, predisposing factors and details of topical and systemic medications. Detailed examination was carried out in all the cases to find out the precise distribution and morphology of the lesions and to detect the evidence of any pre-existing skin disorder or any associated dermatitis.

\section{RESULTS}

This study was done in 500 patients who attended the DVL OP for 2 successive months in 2016 and 2017 during the period of Dussera, out of which 75 cases were diagnosed to have ACD clinically. A female preponderance was observed in our study as 40 patients (54\%) were females out of which 18 patients (45\%) were in the age group between 5 - 15 years and 22 patients $(55 \%)$ were aged $>15$ years and 35 patients $(46 \%)$ were male out of which 13 patients $(37 \%)$ were in the age group between 5 - 15 years and 22 patients (62.8\%) were aged $>15$ years. Time of presentation after exposure in a total of 75 patients, 3 - 5 days in 23 patients, 6 - 10 days in 22 patients, 1 - 2 days in 18 patients, 10 - 15 days in 10 patients and 15 - 30 days in 2 patients. Patch test was not done due to non-availability.

\begin{tabular}{|c|c|}
\hline $\begin{array}{c}\text { After How Many Days of } \\
\text { Exposure }\end{array}$ & $\begin{array}{c}\text { Number of Patients } \\
\text { Developed Contact } \\
\text { Dermatitis }\end{array}$ \\
\hline $1-2$ days & 18 \\
\hline $3-5$ days & 23 \\
\hline $6-10$ days & 22 \\
\hline 10-15 days & 10 \\
\hline 15-30 days & 02 \\
TOTAL- 75 \\
\hline $\begin{array}{c}\text { Table 1. Clinical Presentation seen in Patients based on } \\
\text { Duration after Exposure to Semecarpus anacardium }\end{array}$ \\
\hline
\end{tabular}

Antihistamines and topical steroids were given as first line of treatment in patients. In few severely affected patients, systemic steroids were given.

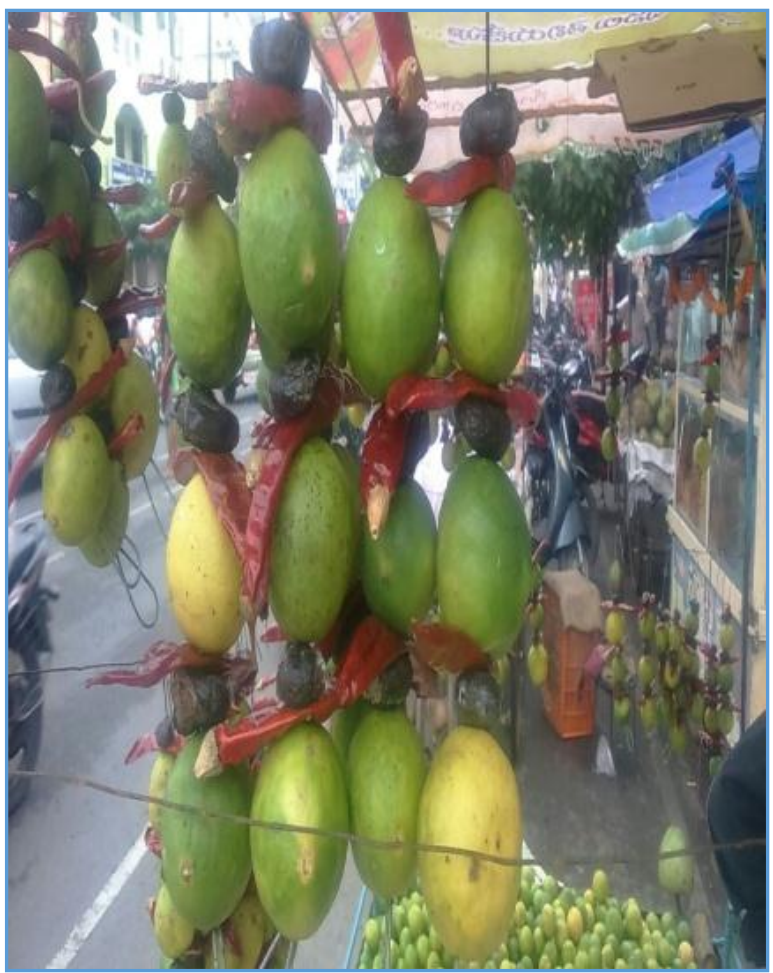

Figure 1. It shows various Remedies to Revert Evils Eye in India (Superstitious Belief) 


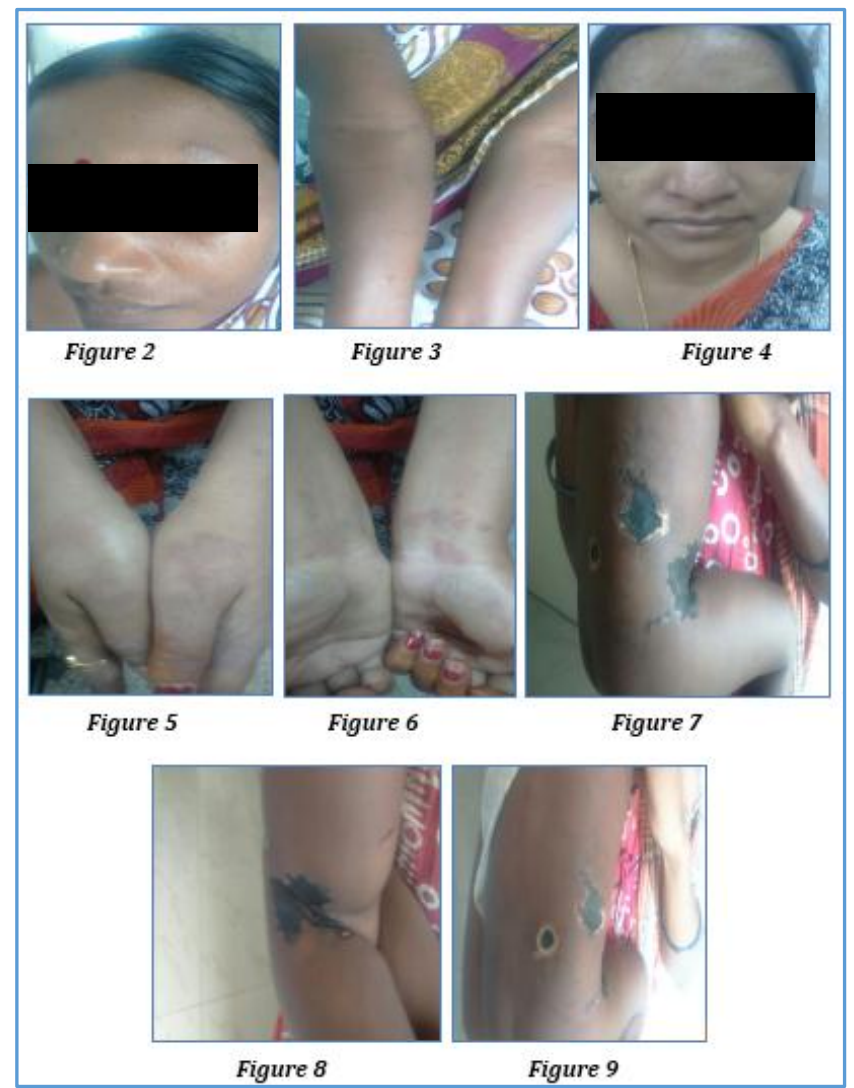

Figure 2, 3, 4, 5, 6, 7, 8, 9. Shows various Presentations of Contact Dermatitis caused by Semecarpus anacardium

\section{DISCUSSION}

It is estimated that $5 \%-10 \%$ of cases of contact dermatitis were determined by plants. Compositae family contains over 13,000 species; some of them are food for consumption, others are cultivated as ornamental plants (chrysanthemums) and others (Arnica, marigold) are medicinal plants. Schimdt in 1986 showed that repeated exposure causes often acute contact dermatitis with frequent relapses and subsequently it becomes chronic with lichenification. When it is located at the level of the elbow or knee it can simulate an atopic dermatitis.

Originally localised lesions at the level of the face, hands and genitals may disseminate and have a bad prognosis, evolving to erythroderma. Also, the remaining dust from these plants may induce air-borne dermatitis.

Semecarpus anacardium is used for various medicinal properties. The fruit and nut extract shows various activities like anti-atherogenic, anti-inflammatory, antioxidant, antimicrobial, anti-reproductive, CNS stimulant, hypoglycaemic, anticarcinogenic and hair growth promoter. ${ }^{4}$

When the tarry oil comes in contact with skin, it produces dermatitis. Medically, it is named as urushiol-induced contact dermatitis. The symptoms include itching, redness, burning sensation, swelling, papules, vesicles, blisters and streaking. Sometimes, it may result in an allergic eczematous contact dermatitis. The rash takes 1 - 2 weeks to run its course and normally does not leave scars. Severe cases have small (1 - 2 $\mathrm{mm}$ ) clear fluid-filled blisters on the skin. Pus-filled vesicles containing a whitish fluid may indicate a secondary infection. Excessive scratching may result in secondary infection, commonly by staphylococcal and streptococcal species. In our series of patients, the erythema was the main clinical symptom. However, we have not performed any patch test due to unavailability. Even though in our study we confirmed the diagnosis based on their clinical history.

\section{CONCLUSION}

So, as Allergic Contact Dermatitis is an eczematous reaction that occurs as an immunological response following exposure to a substance to which the immune system has previously been sensitised. Different factors like age, sex, atopy, social and cultural practices, habit of parents and caregivers and geographic changes affect the patterns of ACD and their variable clinical presentation. And even Semecarpus anacardium is used for various medicinal properties as antiatherogenic, anti-inflammatory, antioxidant, antimicrobial, anti-reproductive, CNS stimulant, hypoglycaemic, anticarcinogenic and hair growth promoter, people who were sensitised with the urushiol present in the Semecarpus anacardium develop ACD who present with various clinical presentations, most commonly within 5 - 10 days after exposure with more female preponderance.

\section{ACKNOWLEDGEMENT}

Authors are thankful to all the patients and healthy controls participated in the study.

\section{REFERENCES}

[1] Sharma K, Shukla SD, Mehta $P$, et al. Fungistatic activity of Semecarpus anacardium Linn. f nut extract. Indian J Exp Biol 2002;40(3):314-8.

[2] Ghorpade A. Nutty dermatitis - marking nut dermatitis after use as a home remedy. Clin Exp Dermatology 2009;34(8):e997-e8.

[3] Bhatia K, Kataria R, Singh A, et al. Allergic contact dermatitis by Semecarpus Anacardium for evil eye: a prospective study from central India. Indian J Basic \& Appl Med Res 2014;3(3):122-7.

[4] Shukla SD, Jain S, Sharma K, et al. Stress induced neuron degeneration and protective effects of Semecarpus Anacardium Linn. And Withania Somnifera Dunn. In hippocampus of albino rats: an ultrastructural study. Indian J Exp Biol 2000;38(10):1007-13. 